\title{
Creativity and working knowledge: what healthcare managers can learn from architects
}

\author{
Steven Cranfield \\ London School of Hygiene and Tropical Medicine, London, UK
}

\begin{abstract}
Purpose - The purpose of this paper is to describe a qualitative observational study of how middle managers in healthcare in the UK on a work-based masters programme in leadership were introduced to foundational aspects of creativity and delivering innovation through an assignment on contemporary architectural design. Design/methodology/approach - The assignment involved individual research of a recent architectural design followed by group poster presentations of findings and structured analysis. No prior knowledge of design was required. An activity theory approach was used to explore common principles of creativity and leading innovation, key features of design processes and tools for facilitating implementation.

Findings - A total of 89 managers in seven cohorts completed the assignment. Data from process records and group work, artefacts and follow-up evaluation questionnaires were analysed within an interpretive approach. Analysis of data lent support for the view that exploring architectural design as an activity system helped participants to develop conceptual and applied links between management performance, creative collaboration and delivering innovation in their own, different field of practice. Where participants expressed limited selfefficacy regarding the capacity for fostering creativity, this was usually ascribed to systemic inhibitors.

Practical implications - Exploring architectural design could provide a relatively low-cost, highly stimulating component of management development programmes seeking to harness the contribution of creative industries to foster work-based creativity and innovation.
\end{abstract}

Originality/value - This study explores a novel use of architectural design within the context of workapplied development programmes for healthcare managers.

Keywords Activity theory, Creativity, Innovation, Architectural design, Healthcare management, Working knowledge

Paper type Research paper

\section{Public sector management, innovation and creativity}

How do managers translate innovative ideas into real-world practice? Addressing this question poses challenges for managers tasked with reform of public sector services (Blackler and Kennedy, 2004). Discourse on public sector management (Wright and Pandey, 2010), as on management in the business sector (Bass, 1997), reflects an increasingly globalised neoliberal vision of delivering radical reform of services (Connell et al., 2009). Equally, it has tended to shift from an emphasis on the strongly normative and transactional towards an increased reliance on the notion of the transformative, based upon values of "participation, consultation and inclusion" (Silvestri, 2007, p. 39).

Management research highlights close connections between transformational approaches, delivering innovation and fostering the capacity for creativity in self and

(C) Steven Cranfield. Published in Journal of Work-Applied Management. Published by Emerald Publishing Limited. This article is published under the Creative Commons Attribution (CC BY 4.0) licence. Anyone may reproduce, distribute, translate and create derivative works of this article (for both commercial and non-commercial purposes), subject to full attribution to the original publication and authors. The full terms of this licence may be seen at http://creativecommons. org/licences/by/4.0/legalcode.

Thanks to the following: Dr Fernando Rihl and Ali Zaidi for discussions on architectural design and creative design, respectively; Dr Sheila Marsh and JudStone, module tutors; Marsaili Cameron and Trevor Dolan, course tutors; Gail Langley and Sibyl Coldham, independent academic consultants; all course participants, including the one giving permission to include their poster and the anonymous peer reviewers of this study.

\section{$-$}

Received 30 January 2020 Revised 2 April 2020 Accepted 14 April 2020 
JWAM

12,2

others (Bassett-Jones, 2005; Epetimehin, 2011; Paulus and Nijstad, 2019). In healthcare, however, all but the simplest innovation or idea needs to address a complex range of factors within and outside the organisation (Greenhalgh et al., 2004). Implementation of a new idea, practice or system is highly dependent on leaders' balancing needs and interests of diverse stakeholders, negotiating complex ownership and resourcing arrangements and working with professionally autonomous groups of staff members (Dawson, 1999). As in other public sector settings, innovation in healthcare is "beset by complexity of a different order to that in more hierarchical organizations" (Iles and Sutherland, 2001, p. 18). Accordingly, there is growing acceptance in this field of the need to work collaboratively, including with patients and service users (World Health Organization, 2017).

An associated challenge of these developments is to recognise a notion of creativity as normative and potentially distributed rather than confined to certain privileged individuals or roles (Sonnenburg, 2004). If this notion is integrated into leader and follower practice, it is argued that all can be empowered to be innovative and creative, one of the espoused goals of transformational leadership (Bass and Riggio, 2012). However, managers of public sector services may seldom see their work as having a creative dimension. In healthcare, most nonclinical managers tend to stay in post for shorter periods than their clinical colleagues do and are often not able to see an innovation through from start to finish, nor learn from the results (Cameron et al., 2001). Indeed, healthcare managers and leaders may be perceived as anticreative if seen as limiting the scope of clinical activity and research or undermining medical careers (Gray, 2000). How can we promote a notion of purposeful, directed creativity (Plsek, 2010) that has a beneficial effect on the thinking and work practices of healthcare managers?

\section{The role of arts-and-management research and interventions}

To help answer this question, research has been turning to practitioners in the creative industries (Smith, 1998) as inspired, critical models of improvisational leadership (Springborg, 2012; Latham, 2013). There is a growing body of knowledge about leadership and management practices and creativity exploring synergies between these different subject areas (Paulus and Nijstad, 2019). The creative industries are more and more used in public sector leadership and management development programmes as a way of generating insights into "non-rational" creative processes and the complexities of embodied leadership (Mikenas, 2000; Parush and Koivunen, 2014), for example, to unleash creativity in subordinates (Politis, 2004) or to engender a sense of hope (Helland and Winston, 2005) or resilience (Bennis et al.,2015). Methods used include guided study, structured visits, motivational speakers, master classes, reflection on practice and experiential and participatory activities (Schedlitzki et al., 2015). Proponents of arts-informed approaches claim that these open up spaces for understanding leadership in non-traditional ways and promote insights into emotional as well as cognitive processes of leaders (Latham, 2013). The contribution of these approaches to the development of skills and attributes of mindfulness and emotional intelligence in leaders Garavan et al.,2015 and to increase understanding of ethical and aesthetic dimensions of leadership (Paulus and Nijstad, 2019) are amongst ongoing areas of research. A challenge of these methods is to enable them to bridge rather than widen the gap between creative self-expression and managerial/leadership practice (Parush and Koivunen, 2014). Workshops on performance-type methods such as group drumming, mask making and storytelling, for instance, may be highly stimulating but participants may struggle to relate these and similar activities to anything actionable in their work contexts. Some such activities may be deemed unacceptable on religious or cultural grounds; factors such as emotional stress, personal disclosure or loss of face may also impede their use. Arts-based methods can be costly to commission and raise questions of return on investment.

By contrast, other arts-based methods away from the arena of performance, for instance, those coming under the umbrella of design, may prove more readily acceptable and easier to 
organise and facilitate while being equally stimulating. This study describes the innovative use of architectural design (a creative industry) as a focus of learning in an academic workbased leadership programme for middle managers in the UK's National Health Service (NHS). The programme was based on an activity theory approach (see below) intended to help participants to analyse and reflect on their overall systems of work-based activity interpreted in this context as those systems, structures, tools and professional and managerial practices implicated in commissioning, planning, delivering and evaluating care.
Healthcare managers learn from architects

\section{The leadership development programme: an activity theory perspective}

The programme discussed in this study was a work-based masters in leadership in health and social care, commissioned by the National Health Service Executive (NHSE) and delivered through two universities in England. Its main aim was to develop in health and social care services a leadership style and culture appropriate to the values and challenges set out in the UK government's modernisation agenda (Department of Health, 2000). At the top of this agenda was improvement of public services and the policy environment was conducive to promoting learning centred on the working environment and on "working knowledge" (Symes and McIntyre, 2000) in which knowledge and its production are construed as distributed throughout society, including the workplace, rather than concentrated in academia. Programmes commissioned by the NHSE were required to adopt a broadly work-based learning approach (Johnson, 2000). Delivered part-time over three years, the programme discussed here was designed for managers at the meso (service) level of the organisation (House et al., 1995). Participants included clinicians, practitioners, social workers, allied health professionals and managers leading services. Professional backgrounds represented included medicine, nursing, speech and language therapy, pharmacy, gerontology, midwifery, critical care, social services, child protection, information technology, substance misuse and sexual health.

In common with other development programmes sponsored by the NHSE seeking to effect systemic, cultural change (Blackler and Kennedy, 2004), the masters programme adopted an activity theory approach (Engeström, 1999). Activity theory, with its focus on systems and the role within these of tools and equipment, informal and formal procedures, and the division of labour (Engeström, 1999), is an increasingly familiar contributor to the repertoire of tools for theorising professional development and management and leadership practice (Boud and Brew, 2013), including in healthcare (Boyle and Mervyn, 2019). Activity theory seeks to encompass environmental factors, personal history and motivations, the role of culture and the artefact, and complex real-life activity (McCaslin, and Hickey, 2001; Roth and Lee, 2007). Activity theory can be summarised as conforming to five principles (based on Engeström, 2014):

(1) The prime unit of analysis is the system to which individual and group actions, albeit independent, are subordinate.

(2) Systems are communities of multiple points of view, traditions and interests and how these different perspectives mesh or collide across and between levels of a community (see MacVaugh and Schiavone, 2010) determines the overall efficiency of the system as well as the course of an innovation's adoption within it (see Lee, 2011).

(3) Activity systems can be fully appreciated only in their cultural and historical contexts: hence the significance for analysis of taking into account context and process as well as content (see Pettigrew, 1987; Stockdale and Standing, 2006).

(4) Activities are open systems which contain inherent contradictions or double binds (Bateson, 1972) which evolve from structural tensions that accumulate over time. These contradictions are expressions of a "paradoxical injunction" (Bateson, 1972), 
JWAM

12,2

178 that is, an instruction to do two mutually contradictory things, neither of which can be ignored. An example would be to exhort a leader to embody the values of "participation, consultation and inclusion" (Silvestri, 2007, p. 39) while requiring them to mobilise opinion to secure implementation of a change in which frontline staff members have had no direct say.

(5) Contradictions may lead to challenge of the status quo but fundamental systemic change is effected only when there is a deliberate and collective effort to envision and create a wider set of possibilities than the previous activity system.

These principles are pertinent to the present discussion since it is precisely the ability to create and deliberately harness a collective vision for change that transformational leadership aims to foster. Blackler and Kennedy (2004) argue that using activity theory has the advantage for public sector leadership development programmes of helping "participants develop a resilient approach to the conflicts and tensions in their organizations and re-engage with their objectives" (p. 182). This study concentrates on the aforementioned principles as exemplified in a specific part of the programme: an assignment which required research into architectural design. This assignment was not summatively assessed but integral and formative to the learning fed forward into a project bringing professional development as a practitioner-researcher to bear on a contextualised problem in the workplace (Costley and Abukari, 2015).

\section{Why architectural design?}

"Architectural design" refers to taking the parts of a structure and turning them into a whole system. It has been defined as "that part of the design of a building produced by an architect, which encompasses technical, structural, aesthetic and financial aspects" (Davies and Jokiniemi, 2008, p. 20). The rationale for the choice of architectural design was based on two considerations: impact and working across boundaries.

\section{Impact}

Architectural design is a realm of innovative practice with a demonstrable, enduring impact on a local economy and on citizens' quality of life. Moreover, much recent architectural design is explicitly concerned with the health impact of its products (see Lavin et al., 2006): "survival depends as much on shelter as on health and we are nearly as dependent on buildings as we are on our bodies" (Lloyd, cited in Iles, 2007, p. 2). Understanding how a different field of practice articulates the notion of impact on the lives and well-being of local communities would, the programme team assumed, generate related "working knowledge" (Symes and McIntyre, 2000) for managers in health and social care tasked with equivalent concerns.

\section{Working across boundaries}

The assignment was predicated on the potential for learning about important facets of creativity and innovation nestling in the boundaries between disciplines and organisations (Carlile, 2004). It required managers to take a close look at how a creative idea in a different field of professional practice to their own was turned into a tangible, collaboratively created product and how that learning could be applied to and across their own work contexts. This involved interrogating the connections between creative concept, innovative product and associated management and leadership behaviours: as Muller (2018) observes, "Conceptual thinking is a must for an architect. However, the capability to translate these concepts in real world activities or implementations is crucial" (p. 11). These levels, connections and stages in 
the "innovation journey" (Van de Ven et al., 2008) of a new architectural design are susceptible to public scrutiny through a range of artefacts and sources of information. The role of culture and the artefact, important aspects of knowledge transfer highlighted by Engeström (1999), are very evident in architectural design (Halin et al., 2004; Aksenova et al., 2014): in particular, the aesthetic and functional achievement that a finished construction represents may have been, and continue to be, the site of tensions, conflicts, competing value systems and power inequalities (Hatherley, 2001). Ways in which objects of activity through which an initial idea is translated into a real-world artefact, and in which new objects of activity are reconfigured (for example, in how a new building is used symbolically or in practice), emerge particularly clearly in recent architectural designs (see Tschumi, 1996). This emphasis on design was also carried through into the method (designing a poster) used to explore the topic.

\section{The assignment in context}

Participants were briefed to select for studying the genesis and development of an innovative architectural design project (completed within the previous 10 years), to carry out individual desk research $(4 \mathrm{~h})$, and to present and discuss findings in poster displays assembled at a group workshop ( $3 \mathrm{~h}$ ) three weeks later. Themes arising from posters were collated and analysed in structured group activities, to identify common principles of creativity and innovation, as mediated through Amabile's (2006) typology of six categories of managerial practice affecting creativity: (1) challenge; (2) freedom; (3) resources; (4) work-group features; (5) supervisory encouragement; and (6) organisational support (see Table 1).

The aim was to open up avenues for work-based inquiry and to generate a rich source of "working knowledge" (Symes and McIntyre, 2000), pragmatically grounded but sufficiently removed from the exigencies of participants' workaday worlds to expand not constrain thinking. They were thus asked not to choose new hospital constructions. No prior knowledge of architectural design was assumed or required. However, tutors sought preliminary advice from a practising architect and a creative designer and incorporated this in the accompanying briefing and study materials.

\section{Methods and findings}

Data were collected from a total of 89 participants from seven cohorts, including participants' posters, recorded group activities at workshops, participant evaluations through anonymised questionnaires and debriefings amongst the tutor team, and shared with an independent researcher who attended a number of workshops as an observer. Workshop data were recorded photographically and in transcribed workshop flip charts. All data were combined and analysed thematically within an overall interpretivist approach (Patton, 1990). The researcher and tutor team read and re-read written data from all seven cohorts to identify additional themes to those highlighted by the conceptual frameworks of Amabile (2006) and Engeström (1999). Initial codes were identified, discussed and shared with the wider course team with samples of data and used to build up themes. During the second examination of data, it was concluded that after cohort 5 the point of saturation (Morse, 1994) had been reached. The researcher then identified participant quotations that were congruent with overarching themes. An advanced draft was shared with two independent educationalists, along with codes and themes, and amendments incorporated.

This study reports on the analysis of verbal data from workshops and evaluation questionnaires. An example of a poster (Plate 1) is included for illustrative purposes to show how participants could quickly assemble materials to communicate findings clearly and creatively.
Healthcare managers learn from architects 
JWAM

12,2

180

\begin{tabular}{ll}
$\begin{array}{l}\text { Thematic } \\
\text { analysis-group } \\
\text { task }\end{array}$ & $\begin{array}{l}\text { Components of an } \\
\text { activity system } \\
\text { (Engeström, 1999) }\end{array}$ \\
\hline $\begin{array}{c}\text { (1) Common } \\
\text { principles of } \\
\text { innovation }\end{array}$ & $\begin{array}{l}\text { Rules } \\
\text { Community }\end{array}$ \\
& \\
$\begin{array}{c}\text { (2) Features of } \\
\text { design } \\
\text { process }\end{array}$ & $\begin{array}{l}\text { Informal and formal } \\
\text { procedures }\end{array}$ \\
&
\end{tabular}

Cler purpose clear end point

Make a statement

Community value-added

value: "More than just a ..."

Responded to local

environment

All are collaborations

Collaboration

Planning - formal and

informal

Sustained energy

Emergent changes

Getting right expertise at right

time

Ownership/leadership

Maintaining motivation

Willingness to take risks

(3) Tools for facilitation

Mediating artefacts:

tools and signs

Division of labour

Money

Competition

High tech computer modelling

Public relations and

consultation

Explaining/sharing vision -

dialogue, including with users

Appropriate resources

Expertise

Brief is prescribed within

existing constraints, so need to

search for innovation/

creativity

Even architects make

compromises

Environmental considerations

count

Technical achievement can

come through lateral thinking
Six categories of management practice affecting creativity (Amabile, 2006)

4 Work-group features

"Autonomy around process fosters creativity" (Amabile, 2006, p. 20)
Table 1.

Chart of findings from one workshop
Design projects researched included: redevelopment programmes; shopping centres; ecological centres; football stadiums and other sports facilities; housing and regeneration projects; churches; public gardens; bridges; office buildings; sculptural installations; and numerous civic landmarks. In researching the history of a project, most relied on secondary online sources while some spoke to those involved in the design of a project. Several focussed on a construction close to home or work; others explored further afield. 

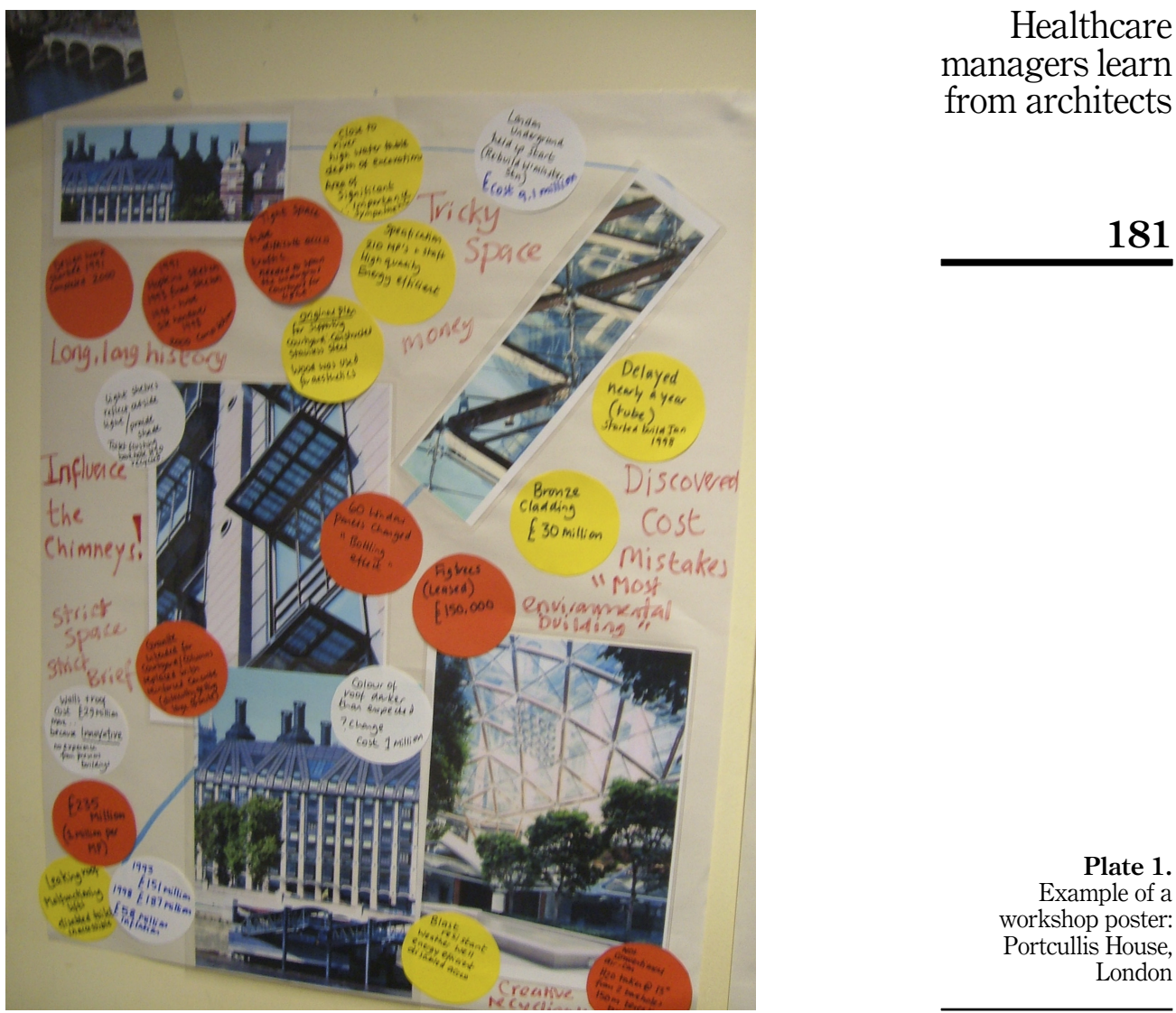

181

Plate 1. Example of a workshop poster: Portcullis House, London

Each cohort workshop split participants into sub-groups who were asked to discuss their findings in relation to four categories: (1) common principles of the innovative design; (2) features of the design process; (3) tools needed for facilitation of the process; and (4) "Aha!" moments (unanticipated learning points). These categories broadly mapped onto components of activity theory such as tools and equipment, informal and formal procedures, division of labour and so on (Engeström, 1999). Sub-groups reconvened to synthesise findings in one composite chart.

Table 1 presents one cohort's composite findings. The far left-hand column shows the four categories of the group task, with the corresponding components of an activity system in the adjacent column. The column headed "Collated sub-groups' findings" shows verbatim findings of sub-groups' discussions in the subsequent plenary. The far right-hand column counterpoints findings with tutors' identifications of equivalences in Amabile's (2006) categories of management practice affecting creativity. This text was a prior reading for the assignment and offered by tutors facilitating the discussion. Amabile (2006) discusses how creativity is often undermined unintentionally in work environments and application of the categories was intended to enable participants to appreciate connections between findings emerging from the assignment and the literature on management and creativity, especially that which looks at the dynamic between unleashing creativity in the workforce and meeting business imperatives. 
JWAM

12,2

182
Analysis

The following section expands on the findings in Table 1, and draws upon the analysed data from the first five cohorts. The analysis is presented in terms of the five principles of activity systems broadly based on Engeström (2014) discussed earlier.

\section{(1) A systemic perspective}

Given the recent realisation of projects, attention focussed on the early implementation stage of an innovation's journey (Van de Ven et al., 2008). Most participants found the creativity, determination and dedication of architects, designers and structural engineers and their teams inspirational in terms of the ability to steer a creative idea through to construction, deploy resources and negotiate complex demands of stakeholders. While some referred to "maverick designers" the emphasis overall was on creativity within constraint, tempered by a sensitivity to collaboration and collective vision. Some commented on the drive of charismatic individuals in terms that showed the influence of the idea of the hero-innovator (Georgiades and Phillimore, 1975). Others emphasised complex webs of influence and discussed the challenge regarding their own capacity for an equivalent creativity to that of designers, modulated through the expectation on them to be exemplars in "stretching the team for excellence and innovation" (NHS Leadership Academy, 2011, p. 10). Some were surprised to find some architects referring to their relatively low status in the construction team, answering to the demands of contractors, engineers and customers; their sense of creativity was a casualty of this loss of status and professional disempowerment (see Brown et al., 2010).

(2) Multiple points of view, traditions and interests

Discussions prompted the realisation that a strong belief in aesthetic values was compatible with making compromises, including in projects which came in under budget, thus incidentally illustrating Amabile's (2006) finding that "adding more resources above a 'threshold of sufficiency' does not boost creativity" (p. 7). When participants looked into the norms and workings of the activity systems in more detail there were some unexpected findings. Some expressed surprise that architectural design studios could often be strongly hierarchical spaces, in which division of labour was often linked to the master-apprentice tradition (see Schön, 1987): issues such as intellectual property, reward of individual effort, internships and a long hours work culture predicated on project-based freelancing, could work for and against generation of new ideas. Some designers were reported as regretting the risk aversion of public sector clients who shied away from innovation. This message struck home to several participants responsible for commissioning new healthcare services in which the views of certain powerful stakeholders were unduly cautious.

\section{(3) Context and process}

The importance of designers having a sound knowledge of local context came across strongly. Awareness of local history was often used to conceptualise a new design, and root it in local knowledge and customs. This was especially the case with projects that redeveloped civic landmarks to serve a different function and constructions in conspicuous locations, such as a new rowing shed along a popular riverside walk or a new cathedral in a city centre. Tools which designers used to embody this situated knowledge included storytelling and, allied to this, strong public relations and influencing skills. Participants appreciated that the workflow in architectural design, as in healthcare management, arises from the interface of subject, object and mediating artefact in ways that often call for "deep customization" (Mandl and Kohane, 2012). This resonated for many with the narrative in health of personalised care (Needham, 2011). 
Sensitivity to contradiction surfaced in relation to divergent messages about managing innovation and risk, alluded to above. This may have reflected the nature of the activity systems being compared: risk management is a major concern for design (Charlton Smith, 2007) and construction (Flanagan and Norman, 1993) as well as for public sector services (Rana et al., 2019). The working environments of participants and designers demand strong skills and capacities for leading innovation against a complex, shifting background of financial, legal, ethical and professional constraints. Participants appreciated that risk managers learn from architects management versus traditional public sector prudence (Kane and Patapan, 2006) is a balancing act common to architectural design and health and social care. They also recognised that allowing others autonomy to generate or implement innovative ideas - the kind of creative space found to be often both hard and narrowly won in the case of some architectural designers - depends on leaders' themselves having a measure of authority, as well as the disposition, to take risks. By virtue of their position at the meso level in organisations, participants were conscious of being on the receiving end, as well as transmitters of the paradoxical injunction to be simultaneously a risk taker and a safe pair of hands. Exploring this paradox further was a productive focus for their work-based project.

(5) Deliberate, collective effort for change

Organisational support was seen by participants as crucial, particularly when steering innovation deliberately and collectively through intricate political processes with multiple stakeholders. Design projects helped to illustrate how decisions about innovations had been reached in complex organisations and partnerships, and how networks of power and influence play a major part in introducing and rolling out a project. Participants recognised that designers are equally under pressure for results, while maintaining adherence to project and organisational goals and ethical and professional codes. All appreciated the importance of teamwork and collaborative processes - putting people together who have the right chemistry - seen as central to the work-group features of creatively managed organizations (Amabile, 2006). Tools used by designers that participants identified as facilitating this goal ranged from tangible resources such as financial backing to soft skills such as familiarity with tendering procedures.

\section{Evaluation and discussion}

Evaluation did not seek to measure longer term impact of the assignment on managers' practice, and was limited to self-reporting and summative assessment of work-based projects. An anonymised evaluation questionnaire was emailed to participants three months after the assignment and after completion of their work-based assessment on delivering an innovation. One question requested feedback on perceived impact of the assignment on management learning and practice. Twenty-nine participants provided feedback on this question, of which the following extracts are representative:

I observed the creativity, determination and dedication of [an architect]. What could I learn from this to transform my practice? [. . . I I remember purpose, dedication, motivation and reward.

I recall the inspiration and driver for the [ecological design] project.

Before the assignment, I did not view any of my current projects in work as particularly innovative; this may have been my interpretation of the concepts of innovation and creativity.

Successful innovation demands dedication, energy and motivation. 
JWAM

12,2

184

"Demands from managers appeared to be denying me further from the creative aspects of my role and [...] were distorting and destroying networks of opportunity. I realised I could develop ideas freely, be clear on what I want to achieve but work within systems to achieve my goal."

Process records and discussions with tutors also indicated that the assignment excited participants' interest, enriched understanding of environmental and ecological issues and enabled them to engage or "re-engage with their [organizational] objectives" (Blackler and Kennedy, 2004, p. 182). Some participants used aspects of the assignment's methodology in their innovation projects, for instance using digital collages to explore new hospital builds with opinion formers. The assignment appeared to have been successful in introducing participants to core concepts of creativity and innovation and indicated that it had the potential to impact positively on a number of leadership skills, including development of thinking in a different way.

Research focussing on managerial identity formation has highlighted "the double binds encapsulated in the art-and-management discourse [which] may be paralyzing in some contexts and inspiring in others" (Parush and Koivunen, 2014, p. 104). An arts-based activity that arouses expectations or unleashes a sense of creativity that managers struggle to realise meaningfully in the work setting is a missed opportunity at best and personally undermining at worst. However, that is not a compelling argument for side-stepping the struggle or the paradoxes. Activity theory draws attention to such double binds as destablisers of the status quo and potential motors of learning. As discussed, healthcare leaders in England are expected to "secure transformation and improved patient outcomes" (NHS England, 2015, p. 3) through systemic innovations that question accepted practice: paradoxes and disturbances are part of the innovation journey. The key here is to ensure that any artsinformed activity is conducive to personal and professional growth and impactful on practice. Contemplating and analysing a realised project from idea-generation to realization enabled participants to pinpoint processes by which challenges facing its creation had been addressed. This provided a counter-balance to those narrative strands in public sector service discourse in which policy-driven innovation is construed as a form of "creative destruction" (Nolan and Croson, 1995), a prelude to downsizing to free up resources (Luthans, 1999). As one participant observed

The current climate is one of insecurity, distrust and lack of resources, all of which are identified to block creativity.

Architects were seen as skilled in simplifying complex information about the social and environmental impact of a new construction. The ability to simplify is an admired leadership quality, yet generally agreed to be one of the hardest to achieve (Isaacson, 2012). Precision, harmony and routine can help to ensure predictability and instil a sense of fairness amongst team members (Frederickson, 2000). Managers could appreciate the virtues of streamlined projects managed with and creating the effect of simplicity. One participant's feedback illustrated this point: it reflected on what they had learnt from an innovative construction with the comment "IMPACT - simple + elegant BUT complex calculations on stress and new use of glass".

A shared challenge for healthcare managers and architectural designers is to meet business imperatives in ways that earn them sufficient autonomy for creative approaches to problem-solving (Kaufmann, 2001). Some participants felt squeezed rather than incentivised by a culture of audit (Power, 1997). As one fed back

The current climate in the organization of rationalisation of services, calculating and creating narrow performance measures, closes down rather than opens up new ideas. 
Yau (1991) argues that a positive self-image enhances the possibilities for creative production. However, professing a confident creative self-image as a leader was seldom straightforward for some managers in this study, for reasons previously discussed. Comparing how leaders and teams in another, no less audited professional domain exercised creativity provided participants with a launch pad for exploring ways in which they valued, or might consider revaluing their and their teams' creative potential.

\section{Implications for arts-and-management research}

Leadership and management development strategies designed to share best practice between different contexts, sectors and domains of practice (see Carter et al., 2005) often focus on the object or outcome of an activity system rather than the working of the system as a whole and the dynamic interactions between elements, systems and levels within systems (Robert et al., 2010). The architectural design assignment invited participants to focus on a real-world object and enabled them to explore critical aspects of collaboration in a sufficiently different but not wholly alien type of activity system the workings of which could not simply be dismissed as having marginal relevance to participants' jobs. Indeed, the architectural design studio has hitherto provided the focus for exploring key aspects of learning about reflective professional practice generally (Schön, 1987). This produced immediately intelligible implications for management theory and practice in their own systems: integral aspects of knowledge and practice were translatable across boundaries (Engeström, 2001; Carlile, 2004).

Evaluation also lent support for Blackler and Kennedy's (2004) argument that an activity system approach can help develop individual and organisational problem-solving and resilience. While it led some to question their capacity for fostering a sense of creative agency in the workplace it tended not to reinforce any perceived lack of self-efficacy ("I'm just not that creative") but to prompt solution-focussed reflections on systemic barriers to creativity ("I realised I could develop ideas freely, ... work within systems to achieve my goal”). Only a minority reported they had very limited scope to apply the learning and these views were linked to a sense of frustration with their organisation's lack of receptivity to change.

This study aims to contribute to debates about "the aesthetic turn in leadership development" (Schedlitzki et al., 2015, p. 413), in particular those related to public healthcare project management and delivering innovation. Within the limitations of its observational method and scope, its findings suggest that architectural design shows considerable potential as a focus of initial learning about work-based creativity for those leading and managing in a different field of practice, provided that it is strongly linked to theory and practice in the workplace. Architectural design may show similar potential when combined with other fields to the one discussed here, especially where there is a common focus on initiating cross-disciplinary, work-based explorations of the collaborative nature of creativity, innovation and decision-making. As such it merits further investigation by management and work-based learning researchers in other fields. While management theory (Bartunek and Egri, 2012) argues that the search for a template for creative management is an elusive goal, managers and their teams have much to learn and take inspiration from architectural design.

\section{References}

Aksenova, G., Tahrani, S. and Forgues, D. (2014), "Cultural-historical activity theory to introduce transformations in architecture and construction: a case study", Paper presented at 30th EGOS Colloquium, 3-5 July, 2014, Rotterdam, The Netherlands, available at: www.researchgate.net/ publication/267332415_Cultural-Historical_Activity_theory_for_introducing_transformations_ in_architecture_and_construction._A_case_study (accessed 25 January 2020).
Healthcare managers learn from architects 
JWAM

12,2

186

Amabile, T. (2006), "How to kill creativity", in Henry, J. (Ed.), Creative Management and Development, 3rd ed., Sage, London, pp. 18-24.

Bartunek, J.M. and Egri, C.P. (2012), "Introduction: can academic research be managerially actionable? What are the requirements for determining this?", Academy of Management Learning and Education, Vol. 11 No. 2, pp. 244-246.

Bass, B.M. (1997), "Does the transactional-transformational leadership paradigm transcend organizational and national boundaries?”, American Psychologist, Vol. 52 No. 2, pp. 130-139.

Bass, B.M. and Riggio, R.E. (2012), Transformational Leadership, Psychology Press, New York, NY and London.

Bassett-Jones, N. (2005), "The paradox of diversity management, creativity and innovation”, Creativity and Innovation Management, Vol. 14 No. 2, pp. 169-175.

Bateson, G. (1972), Steps to an Ecology of Mind: Collected Essays in Anthropology, Psychiatry, Evolution, and Epistemology, Ballantine Books, New York, NY.

Bennis, W., Sample, S.B. and Asghar, R. (2015), The Art and Adventure of Leadership: Understanding Failure, Resilience and Success, John Wiley and Sons, Hoboken, New Jersey, NJ.

Blackler, F. and Kennedy, A. (2004), "The design and evaluation of a leadership programme for experienced chief executives from the public sector", Management Learning, Vol. 35 No. 2, pp. 181-203.

Boud, D. and Brew, A. (2013), "Reconceptualising academic work as professional practice: implications for academic development", International Journal for Academic Development, Vol. 18 No. 3, pp. 208-221.

Boyle, T. and Mervyn, K. (2019), "The making and sustaining of leaders in healthcare”, Journal of Health Organization and Management, Vol. 33 No. 2, pp. 241-262.

Brown, A.D., Kornberger, M., Clegg, S.R. and Carter, C. (2010), “Invisible walls' and 'silent hierarchies': a case study of power relations in an architecture firm”, Human Relations, Vol. 6 No. 4, pp. 525-549.

Cameron, M., Cranfield, S., Iles, V. and Stone, J. (2001), Managing Change in the NHS: Making Informed Decisions on Change: Key Points for Healthcare Managers and Professionals, NCCSDO, London.

Carlile, P.R. (2004), "Transferring, translating, and transforming: an integrative framework for managing knowledge across boundaries", Organization Science, Vol. 15 No. 5, pp. 555-568.

Carter, L., Ulrich, D. and Goldsmith, M. (2005), Best Practices in Leadership Development and Organization Change: How the Best Companies Ensure Meaningful Change and Sustainable Leadership, Pfeiffer, San Francisco, CA.

Charlton Smith, N. (Ed.) (2007), Design Risk Management, RIBA, London.

Connell, R., Fawcett, B. and Meagher, G. (2009), "Neoliberalism, new public management and the human service professions", Journal of Sociology, Vol. 45 No. 4, pp. 331-338.

Costley, C. and Abukari, A. (2015), "The impact of work-based research projects at postgraduate level", Journal of Work-Applied Management, Vol. 7 No. 1, pp. 3-14.

Davies, N. and Jokiniemi, E. (2008), Dictionary of Architecture and Building Construction, Routledge, London.

Dawson, S. (1999), "Managing, organising and performing in healthcare: what do we know and how can we learn?", in Mark, L.A. and Dopson, S. (Eds), Organisational Behaviour in Healthcare, London, Palgrave Macmillan, pp. 7-24.

Department of Health (2000), The NHS Plan, NHS Executive, London.

Engeström, Y. (1999), "Activity theory and individual and social transformation", in Engeström, Y., et al. (Eds), Perspectives on Activity Theory, Cambridge University Press, Cambridge, pp. 19-38.

Engeström, Y. (2001), "Expansive learning at work: toward an activity theoretical reconceptualization", Journal of Education and Work, Vol. 14 No. 1, pp. 133-156. 
Engeström, Y. (2014), Learning by Expanding: An Activity-Theoretical Approach to Developmental Research, Cambridge University Press, Cambridge.

Epetimehin, F.M. (2011), "Achieving competitive advantage in insurance industry: the impact of marketing innovation and creativity", Journal of Emerging Trends in Economics and Management Sciences, Vol. 2 No. 1, pp. 18-21.

Flanagan, R. and Norman, G. (1993), Risk Management and Construction, Blackwell Science, Oxford.

Frederickson, H.G. (2000), The Spirit of Public Administration, Jossey-Bass, San Francisco, CA.

Garavan, T., O'Brien, F. and Watson, S. (2015), "Leadership development and organizational success", in Kraiger, K., Passmore, J., Rebelo dos Santos, N. and Malvezzi, S. (Eds), The Wiley Blackwell Handbook of the Psychology of Training, Development and Performance Improvement, John Wiley and Sons, Chichester, pp. 354-397.

Georgiades, N.J. and Phillimore, L. (1975), "The myth of the hero innovator and alternative strategies for organizational change", in Kiernan, C. and Woodward, F.P. (Eds), Behaviour Modification with the Severely Retarded, Associated Scientific Publishers, Amsterdam, pp. 313-319.

Gray, C. (2000), "Working on morale", British Medical Journal, Vol. 312 No. 7253, pp. S2-S3.

Greenhalgh, T., Robert, G., Macfarlane, F., Bate, P. and Kyriakidou, O. (2004), "Diffusion of innovations in service organizations: systematic review and recommendations", The Milbank Quarterly, Vol. 82 No. 4, pp. 581-629.

Halin, G., Hanser, D. and Bignon, J.C. (2004), "User adaptive visualization of cooperative architectural design”, International Journal of Architectural Computing, Vol. 2 No. 1, pp. 89-107.

Hatherley, O. (2001), A Guide to the New Ruins of Great Britain, Verso, London.

Helland, M.R. and Winston, B.E. (2005), "Towards a deeper understanding of hope and leadership", Journal of Leadership and Organizational Studies Vol. 12 No. 2, pp. 42-54.

House, R., Rousseau, D.M. and Thomas-Hunt, M. (1995), "The meso paradigm: a framework for the integration of micro and macro organizational behaviour", Review of Organizational Behaviour, Vol. 17, pp. 71-114.

Iles, V. (2007), "Images of the NHS: An NHS confederation salon", Discussion Paper, NHS Confederation, available at: www.reallylearning.com/Current_Projects/NHS_Confederation Salons/ImagesoftheNHS.pdf (accessed 25 January 2020).

Iles, V. and Sutherland, K. (2001), Organisational Change: A Review for Healthcare Managers, Professionals and Researchers, NCCSDO, London.

Isaacson, W. (2012), "The real leadership lessons of Steve Jobs", Harvard Business Review, Vol. 90 No. 4, pp. 92-102.

Johnson, D. (2000), "The use of learning theories in the design of a work-based learning course at masters level", Innovations in Education and Training International, Vol. 37 No. 12, pp. 129-133.

Kane, J. and Patapan, H. (2006), "In search of prudence: the hidden problem of managerial reform", Public Administration Review, Vol. 66 No. 5, pp. 711-724.

Kaufmann, G. (2001), "Creativity and problem solving”, in Henry, J. (Ed.), Creative Management, 2nd ed., Sage, London, pp. 44-63.

Latham, S.D. (2013), "Leadership research: an arts-informed perspective", Journal of Management Inquiry, Vol. 23 No. 2, pp. 123-132.

Lavin, T., Higgins, C., Metcalfe, O. and Jordan, A. (2006), Health Impacts of the Built Environment: A Review, Institute of Public Health, Dublin, available at: www.publichealth.ie/sites/default/files/documents/ files/Health_Impacts_of_the_Built_Environment_A_Review.pdf (accessed 25 January 2020).

Lee, C. (2011), Making the Most of Public Services: A Systems Approach to Public Innovation, Report, Knowledge Economy Programme, The Work Foundation, Lancaster.

Luthans, B.C. (1999), "The impact of downsizing on workplace attitudes: differing reactions of managers and staff in a healthcare organization", Group and Organization Management, Vol. 24 No. 1, pp. 46-70. 
JWAM

12,2

188
MacVaugh, J. and Schiavone, F. (2010), "Limits to the diffusion of innovation: a literature review and integrative model", European Journal of Innovation Management, Vol. 13 No. 2, pp. 197-221.

Mandl, K.D. and Kohane, I.S. (2012), "Escaping the EHR trap - the future of health IT", New England Journal of Medicine, Vol. 366 No. 24, pp. 2240-2242.

McCaslin, M. and Hickey, D.T. (2001), "Self-regulated learning and academic achievement: a Vygotskian view", in Zimmerman, B. and Schunk, D.H. (Eds), Self-Regulated Learning and Academic Achievement: Theoretical Perspectives, Erlbaum, Mahwah, New Jersey, NJ, pp. 227-252.

Mikenas, E. (2000), Drumming on the Edge of Leadership: Hand Drumming and Leadership Skills for the New Millennium, Urban Wilde, Lynchburg, VA.

Morse, J.M. (Ed.) (1994), Critical Issues in Qualitative Research Methods, Sage, London.

Muller, G. (2018), "Decomposing the architect; what are critical success factors?", Embedded Systems Institute, Eindhoven, available at: www.gaudisite.nl/DecomposingTheArchitectPaper.pdf (accessed 29 January 2020).

Needham, C. (2011), Personalising Public Services: Understanding the Personalisation Narrative, Policy Press, Bristol.

NHS England (2015), Innovation into Action: Supporting Delivery of the NHS Five Year Forward View, NHS England, Redditch.

NHS Leadership Academy (2011), Leadership Framework: A Summary, NHS Leadership Academy, Leeds.

Nolan, R.L. and Croson, D.C. (1995), Creative Destruction: A Six-Stage Process for Transforming the Organization, Harvard Business School Press, Harvard.

Parush, T. and Koivunen, N. (2014), "Paradoxes, double binds, and the construction of 'creative' managerial selves in art-based leadership development", Scandinavian Journal of Management, Vol. 30 No. 1, pp. 104-113.

Patton, M.Q. (1990), Qualitative Evaluation and Research Methods, Sage, London.

Paulus, P.B. and Nijstad, B.A. (Eds) (2019), The Oxford Handbook of Group Creativity and Innovation, Oxford University Press, Oxford.

Pettigrew, A.M. (1987), "Context and action in the transformation of the firm”, Journal of Management Studies, Vol. 24 No. 6, pp. 649-670.

Plsek, P. (2010), "Directed creativity: how to generate new ideas for transforming healthcare", in Porter-O'Grady, T. and Malloch, K. (Eds), Innovation Leadership: Creating the Landscape of Healthcare, Jones and Bartlett, London, pp. 87-107.

Politis, J.D. (2004), "Transformational and transactional leadership predictors of the 'stimulant' determinants to creativity in organizational work environments", Electronic Journal of Knowledge Management, Vol. 2 No. 2, pp. 23-34.

Power, M. (1997), The Audit Society, Oxford University Press, Oxford.

Rana, T., Wickramasinghe, D. and Bracci, E. (2019), "New development: integrating risk management in management control systems - lessons for public sector managers", Public Money and Management, Vol. 39 No. 2, pp. 148-151.

Robert, G., Greenhalgh, T., Macfarlane, F. and Peacock, R. (2010), “Adopting and assimilating nonpharmaceutical technological innovations into healthcare practice: a systematic review", Journal of Health Services Research and Policy, Vol. 15 No. 4, pp. 243-250.

Roth, W.M. and Lee, Y.J. (2007), "Vygotsky's neglected legacy': cultural-historical activity theory", Review of Educational Research, Vol. 77 No. 2, pp. 186-232.

Schedlitzki, D., Jarvis, C. and MacInnes, J. (2015), "Leadership development: a place for storytelling and Greek mythology?", Management Learning, Vol. 46 No. 4, pp. 412-426.

Schön, D. (1987), Educating the Reflective Practitioner, Jossey-Bass, San Francisco. 
Silvestri, M. (2007), "Doing' police leadership: enter the 'new smart Macho”, Policing and Society, Vol. 17 No. 1, pp. 38-58.

Smith, C. (1998), Creative Britain, Faber and Faber, London.

Sonnenburg, S. (2004), "Creativity in communication: a theoretical framework for collaborative product creation", Creativity and Innovation Management, Vol. 13 No. 4, pp. 254-262.

Springborg, C. (2012), "Perceptual refinement: art-based methods in managerial education", Organizational Aesthetics, Vol. 1 No. 1, pp. 116-137.

Stockdale, R. and Standing, C. (2006), "An interpretive approach to evaluating information systems: a content, context, process framework", European Journal of Operational Research, Vol. 173 No. 3, pp. 1090-1102.

Symes, C. and McIntyre, J. (2000), Working Knowledge: The New Vocationalism and Higher Education, SHRE and Open University Press, Buckingham.

Tschumi, B. (1996), Architecture and Disjunction, MIT Press, Cambridge, MA.

Van de Ven, A.H., Polley, D.E., Garud, R. and Venkataraman, S. (2008), The Innovation Journey, Oxford University Press, Oxford.

Wright, B.E. and Pandey, S.K. (2010), "Transformational leadership in the public sector: does structure matter?", Journal of Public Administration Research and Theory, Vol. 20 No. 1, pp. 75-89.

World Health Organization (WHO) (2017), Patient Safety: Making Healthcare Safer, No. WHO/HIS/ SDS/2017.11, World Health Organization, Geneva.

Yau, C. (1991), "An essential interrelationship: healthy self-esteem and productive creativity", Journal of Creative Behavior, Vol. 25 No. 2, pp. 154-161.

\section{Further reading}

Brooks, G.S. and Daniluk, J.C. (1998), "Creative labors: the lives and careers of women artists", Career Development Quarterly, Vol. 46 No. 3, pp. 246-261.

Brown, G. (2010), "The impact of organisational aesthetics upon innovation in the public sector: an exploration of employee perceptions of changes to workplace design", Unpublished Doctoral Dissertation, Northumbria University, available at: http:/nrl.northumbria.ac.uk/7263/1/guy. brown_dba.pdf (accessed 25 January 2020).

Coulter, J. (2013), "Interdisciplinarity: creativity in collaborative research approaches to enhance knowledge transfer", in Howlett, R.J., Gabrys, B., Musial-Gabrys, K. and Roach, J. (Eds), Innovation Through Knowledge Transfer 2012, Springer, Berlin and Heidelberg, pp. 169-178.

Harries, K. (1998), The Ethical Function of Architecture, MIT Press, Rochester.

Tierney, P. and Farmer, S.M. (2002), "Creative self-efficacy: its potential antecedents and relationship to creative performance", Academy of Management Journal, Vol. 45 No. 6, pp. 1137-1148.

\section{About the author}

Steven Cranfield is an Assistant Professor at the London School of Hygiene and Tropical Medicine. He also lectures at Middlesex University and at Brunel University where he teaches on healthcare management on their MBA. Steven Cranfield can be contacted at: Steven.Cranfield@lshtm.ac.uk

For instructions on how to order reprints of this article, please visit our website:

www.emeraldgrouppublishing.com/licensing/reprints.htm

Or contact us for further details: permissions@emeraldinsight.com 